\title{
Air Mobility, Ten Heads and Universal Authority: Constructing Ravana in the Folk Imagination of Sabaragamua -- A Folkoric Study
}

\section{Lal Medawattegedara*}

Department of Language Studies, The Open University of Sri Lanka, Sri Lanka

\section{Abstract}

King Ravana has already attained a cult status in modern Sri Lanka owing to a resurgence of texts about the legendary king that suddenly flooded the bookshops as well as the mass media. Yet, unseen by this phenomenon, a folktale collection focusing on Ravana was released for public consumption by Gunasekera Gunasoma under the titled Sabaragamuwa Ravana Jana Katha (Ravana Folktales of the Sabaragamuwa Region). This study undertakes a re-reading of these folktales using the folkloric postulate of 'folk ideas' in order to locate the modes of construction of the personality of 'King Ravana' and the insights such constructions might offer into the material conditions of the story creators/tellers/listeners. Folktales tend to carry cultural assumptions, as well as cultural prejudices, of common folks through the implicitly embedded 'folk ideas' in their narratives and this study intends to locate such 'silent' articulations and analyse them to

*Correspondence should be addressed to Mr. Lal Medawaththegedara, Department of Language Studies, The Open University of Sri Lanka, Sri Lanka

Email: lalmedawaththegedara@gmail.com

Dhttps://orcid.org/0000-0003-3351-1889

(Received 27th October 2021; Revised 09th November 2021; Accepted 20th December 2021 (C) OUSL)

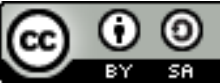

This article is published under the Creative Commons Attribution-Share Alike 4.0 International License (CCBY-SA). This license permits use, distribution and reproduction in any medium; provided it is licensed under the same terms and the original work is properly cited 
understand a group of people's own perceptions about the notions of leaders and leadership.

Keywords: Folktales, Folk Ideas, Silences, Cultural Prejudices, Cultural Assumptions, Construction, Personality

\section{Introduction}

King Ravana, the antihero in the epic Sanskrit poem Ramayanya, a text believed to have been composed between $500 \mathrm{BCE}$ and $100 \mathrm{BCE}$ by a sage named Valmiki, shares one common aspect with Paris, the son of the Trojan King Priam, the antihero of Homer's epic poem Iliad (possibly written in $750 \mathrm{BCE}$ ): both have abducted the legitimate wives of powerful kings and the subsequent events brought forth war and violence upon their subjects and territories. In the text Ramayanaya, King Ravana is the 'demon king' of Lanka who is depicted as imprudent, impetuous and vicious. Yet, in his mother land, and in a region called Sabaragamuwa, where his ancient seat of power was supposedly located, this antihero of Ramayanya is remembered differently. In the orally-transmitted folktales of Sabaragamuwa, a province located in the south-central region of Sri Lanka, he is recast as a just ruler known for his compassionate and respect for nature; in those tales he is also an efficient ruler who combined aggression and benevolence to offer his subject a muchadmired form of leadership. This image of an all-powerful Lankan king at the summit of a powerful kingdom also inspired a recent debate on the historicity of Ravana. The present discussion, owing to its own objectives and scope, does not intend to locate itself in this debate. Instead, the focus of this paper is modest in the sense that the study attempts to understand the mode of construction of Ravana's personality in the folktales narrated in a specific region of Sri Lanka through a parallel reading of the tales. The folktales under focus here are from a collection titled Sabaragamuwa Ravana Jana Katha (Ravana Folktales of Sabaragamuwa), which is a compilation of 56 folktales collected from that region by the renowned folktale collector Gunasekera Gunasoma who has published over 20 collections of Sri Lankan folktales from different geographical regions as well as ethnic groups. ${ }^{\dagger}$

\footnotetext{
${ }^{\dagger}$ His collection of folktales from the Muslim ethnic group of the eastern province of Sri Lanka has been previously studied by this writer under the title Folk Ideas' and 'Worldview' Inscribed in a Selection of Folktales Attributed to the
} 
This study undertakes a close reading of his Ravana folktales to locate and analyse the modes of construction of Ravana as well as is the limits of such endeavours using a folkloric re-reading of the tales.

Folkloric speech acts are usually considered essential constituents of a nation's heritage as well as a mirror of its cultural traditions-in the words of a folklorist, they are "autobiographical ethnography" (Dundes, 2007) of a group of people, or a group of people's description about themselves. At the same time, time and space play essential roles in the meaning of a folktale. As Thompson (1977) suggests, a folktale is a "story which had been handed down from generation to generation either in writing or by word of mouth" (Thompson, 1977). He goes on to argue that a story teller would hold his/her ability to preserve a tale as an act of immense pride: "He usually desires to impress his readers or hearers with the fact that he is bringing them something that has the stamp of good authority..." (Thompson, 1977). Another researcher posits folktales as narratives with a close connection to their material reality: Kirk (1986) assumes that owing to the high "factual content" (Kirk, 1984) of folktales they tend not to be "practical or emotional and intellectual applications" (Kirk, 1984). The thinking offered by these three folklorists about the close bonding between a folktale and its creators/tellers/listeners and the material reality of its creation/telling/hearing would form the backdrop for this study as it attempts to re-read the Ravana folktales of Sabaragamuwa. Why would the tales under focus in this study opt to construct an alternative image of Ravana? What do such constructions tell us about the imagination of the people of the region under consideration? If these tales are a reflection of the people who create/narrate/hear them, then what insights do the tales offer about the people of Sabaragamuwa of a specific time and space? By focusing on the modes of construction of the King Ravana in the selected tales, this study would attempt to answer these questions.

Ravana folktales of Sabaragamuwa by Gunasoma have not come under academic scrutiny; thus, the present study would serve the purpose of fulfilling a gap in scholarship in the area of folklore in Sri Lanka.

Muslim Community of the East Coast of Sri Lanka. See OUSL Journal, 2017, Vol. 12, No. 2, (pp. 5-17). 


\section{Folkloric Introduction to Folktales of Ravana}

Folktale collector Gunasekera Gunasoma's Ravana folktales from the Sabaragamuwa Region feature 56 folktales and was first published in 2016. The book has gone for a second edition in 2019 suggesting its popularity among the Sinhala reading public. Gunasoma's initiative has been sponsored by the provincial administrative divisions of Sabaragamuwa with the objective of preserving the folk heritage of the region. The tales have been narrated for the compiler by storytellers, and he has recorded these speech acts. They have been transcribed in the spoken language of the tellers and the compiler has taken the initiative to offer an extremely short biography of the teller as a footnote at the end of each tale. While this researcher appreciates Gunaskerea's efforts to collect his tales scientifically (only because such attempts are not so common among folktale collectors in Sri Lanka), there are gaps in his methodology. For a folkloric endeavour that received state patronage, Gunasoma does not offer his readers the socio-cultural context required to gain an in-depth understanding of the tales. For instance, he does not offer details about his mode of collection of the tales: How did he locate the narrators? Why are his tale teller's mostly male octogenarians and members of the clergy? What about the others beyond these social categories who might have offered him Ravana folktales? From whom did the present narrators originally hear the story? Were the stories he heard narrated from one location or many? Gunasoma in his short Introduction to his book has not attempted to answer such concerns. Folkloristics encourages tale collectors to improve the authenticity of their tales by offering extensive background information as well as biographies of the tellers and listeners. As the folklorist Weerasinghe (1986) asserts, the entire context of the tale being told needs to be documented: the setting, biographical details of the tellers/listeners; the facial gestures/voice intonations of the teller; the response of the audience. Gunasoma has largely neglected these aspects. The biographies he offers of his narrators are sparse to say the least. At the same time, he does not place his collected tales within the cultural structure of the region, nor does he attempt to locate its function in that social setting. Yet, in spite of these shortcomings, the collector has collected and compiled interesting folk tales about King Ravana from a specific region, an event a reader would have missed had Gunasoma not undertaken the endeavour in the first place. At the same time, 
Gunasoma's collection is the first such collection of Ravana folktales from one geographic location and deserves academic focus.

\section{King Ravana, a Short Introduction as he appears in the version popularized in North India}

Ramayanaya is an epic poem of in classical Sanskrit which follows events of the life of King Rama, considered to be a reincarnation of God Vishnu, who is one of the most powerful and celebrated gods known as the world preserver in the Hindu pantheon. In this poem, King Ravana is identified as the king of Lanka who has 10 heads and 20 arms. He is known for his extreme asceticism which earned him a boon from the Brahma allowing him invincibility from mortal threats posed by gods, demons or spirits. Yet, Ravana violated those powers and embarked on a violent expansion of his territory. God Vishnu incarnates as King Rama to defeat him. When Ravana obsessed by the beautiful wife of Rama, known as Sita, and abducts her Rama declares war on him. Assisted by an army of monkeys and bears Rama engages in a prolonged battle of wit and ferocity with his enemy before slaying him.

\section{Methodology}

One of the important characteristics of a folktale is the notion of 'folk idea.' Folk idea is an implicit unit of narrative which demonstrates the assumptions and conjectures a story creators/narrator/listener commonly agree upon. According to the folklorist Dundes, 'Folk Ideas' are "traditional notions that a group of people have about the nature of humanity, of the world, and of life in the world" (Dundes, 2007). However, Dundes also argues that 'folk ideas' need not be openly apparent in folkloric material and they could be "unstated premises" (Dundes, 2007) which could underlie thought and action of individualsthe present study takes this argument into consideration when rereading the Ravana folktales tales for embedded 'folk ideas.' The objective is to isolate and locate the postulations that construct Ravana in the folktales. Dundes' idea about 'unstated premises' is also a notion that is somewhat reflected in the work of the literary critic Pierre Macherey, specifically in his recommended mode of reading literary texts. All

$\ddagger$ This summary extracted from R.K Narayan's rendering of the Ramayanaya. See References for details. 
speech, according to Macherey "envelopes in the unspoken in order to reach utterance" (Macherey, 2016), and this "silence" (Macherey, 2016), informs us of the "precise conditions for the appearance of an utterance,...its limits...real significance" (Macherey, 2016). The entrenched 'silences' in the folktale sample under consideration in this study would be read for what they state about King Ravana. What are the silent premises woven around Ravana? What is the composite image of Ravana created through those premises? What do such oral/textual constructions reflect of the mind-sets of the tale creators/tellers/listeners?

\section{Results and Discussion}

For ease of analysis and reading, the 'folk ideas' found in the Ravana folktales have been listed and discussed separately. There are five recurring 'folk ideas' extracted from the tales which help construct a narrative around King Ravana. They are, a) Royal lineage of Ravana b) Political unification of ancient Lanka c) Multiple intelligences d) Air power e) Skilled administrator.

\section{a) Royal Lineage of Ravana}

The folktales from Sabaragamuwa posit Ravana as originating from a royal lineage with firmly established roots in both Lanka and India. Across the tales, Ravana's royal lineage is considered as common knowledge though one specific tale, titled Ravana's Birth, offers an extensive account of his lineage. According to this tale, Vishravas, who is an India sage and his wife Idadevi had a son named Vaishravana who ruled a minor domain in ancient Lanka called Vessagiri. When his mother Idadevi died, Vaishravana negotiated with another minor king in Lanka called Sumali to offer one of his daughters, Pushpoththakata, as a bride to his father in India. Two other females, Raka and Malini joined the bride's entourage. The sage ended up marrying all three females. Pushpoththakata bore him two sons, Ravana and Kumbhakarna; Raka, two sons, Dhara and Dushana and a daughter Suparnaka; and Malini one son named Vibhishana.

Interestingly, the folktale creators have combined the royal lineage of ancient Lanka with the priestly stock of India to offer Ravana a powerful blood ties to royalty and priestly sects. Since bloodline is an important 
aspect of ancient Lanka's monarchism, the tale creators have seemingly taken every effort to ensure that Ravana possesses bloodline which could contest, not only leadership in Lanka, but India as well. Ravana is posited as an 'emperor' in the folktales, suggesting that he had power over jurisdictions beyond the land of Lanka. Setting up of significant blood between a prominent personality and respected groups of people is not an unaccustomed narrative strategy for Lankan story tellers. The writer of the historical chronicle Mahavamsa, achieves similar ends by connecting the founding kings of ancient Lanka to the Shakya clan of the Buddha, thus aiding his objectives to celebrate the kings who promoted Buddhist values in the ancient nation. In the eyes of a listener/reader this royal lineage of Ravana establishes the authority of the king as a rightful leader of the people. At the same time, by offering Ravana a royal lineage of Lankan-Indian origin allows a story creator/teller the means to neutralise the 'demon' identity connected with Ravana in the Ramayanaya.

\section{b) Political unification of ancient Lanka}

The folktales under focus in this study make some interesting assumption about the ancient land of Lanka, which was Ravana's seat of power. Politically, the stories suggest that, Lanka was a land of seven domains, namely: Chandragiri (Sabaragamuwa), Indragiri (Kuragala) , Mahedragiri (Ruhuna), Sigiri, Mulagiri (Tangalle), Malayagiri (Kandy) and Helagiri (Devundara). Each was an independent principality governed by a regional king. For unknown reasons King Vaishrvana's-the founder of the Ravana lineage-domain Vessagiri is omitted: a 'silence' that needs attention. Notice that each of these domains is associated with a geographical sign -a rock outcrop (giri). Majority of the rulers of this period, the tales claim, were of local origin belonging to the Yaksha or Naga tribes. The only ruler of Indian origin was Vaishrvana. Ravana had married a princess named Mandodari, who was the daughter of the king of Chandragiri (Sabaragamuwa) called Dumakshaka. That was how Ravana laid claim to Sabaragamuwa as his seat of power. After this marriage Ravana raised a secret army, aided by his father-in-law King Dumakshaka, and conquered all the seven domains. He unseated the king Vaishravana, his blood relation, and expelled him along with his relations, from Lanka-he "chased them to India" (Gunasoma, 2016, pg.20). Ravana was educated in ancient Lanka because "those days the 
globally reputed educational institutes were situated in our country-not in India," (Gunasoma, 2016, pg.14) as one story teller says. After unifying the ancient land of Lanka, it is suggested in sparse syntax that Ravana became a 'chakravarthi' and a 'sakvithi' king. Both these terms suggest universal power as well as righteous governance-though the stories or the tellers do not offer further details.

These stories seemingly admire the bloody wars initiated by Ravana to unify the land of ancient Lanka under one strong ruler-and they pay specific attention to the expelling of rulers of Indian origin from Sri Lanka. In the folk imaginations, one powerful ruler with one seat of power seems to be the preferred form of governance. At the same time, the narratives are careful to purge all Indian influences from Lanka. The silence over the Vessagiri domain governed by a ruler of an Indian origin when naming the seven domains of power in Lanka is an omission deliberately introduced to ignore an achievement by a foreign ruler who invaded and governed a part of Lanka. The event of 'chasing' this king by Ravana is obviously used to counterbalance Vaishravana's invasive initiatives in ancient Lanka.

\section{c) Multiple intelligences}

One of the striking physical attributes of King Ravana is his ten (10) heads. The folktales posit this as a representation of the ten types of intelligence possessed by the king. "Ravana is a highly intelligent person with 10 types of intelligence. What are they?" (Gunasoma, 2016, pg.31) asks one narrator and goes on to name nine (09) of them: universal energies, language, law, military, astrology, music, medicine, techniques of flying and landscaping. The tales go on to suggest that despite such skills, Ravana was a man of "humility, practical ideas and keen intelligence" (Gunasoma, 2016, pg.31). It is evident from this folk idea that the common folks of Sabaragamuwa saw kingship as a site of keen and wider intelligence, combining both practical and bookish knowledge as well as art and engineering. They expected their king to be a man of many skills and facets. He should effortlessly combine the opposite attributes: thus, Ravana is a king who combined aggression and compassion; art and engineering; rationale thought and mysticism. These attributes work towards the countering the 'demon' narrative implanted on Ravana by Ramayanaya. 


\section{d) Air mobility}

Air mobility is the key attribute for which Ravana is remembered in the imagination of Lankan public-though in a setting where his enemies (eg. Hanuman, Rama's commando-styled soldier) could also perform aerobatic abilities these skills would not amount to anything significant. Ravana rode his own version of an aircraft called Dandu Monraraya or the wooden peacock. The folktales, unusually, attempt to offer some detailed information about this peacock-styled aircraft-unusual because folk speech acts tend not to explain away their events involving magic or unbelievable phenomena. Accordingly, the Dandu Monaraya is made from wood and consists of two flexible wings that perform the motions of an actual bird's wings. "The wings go up and down just like the motions of a real bird" (Gunasoma, 2016, pg.31) explains one storyteller. The flying mechanism this aircraft did not involve science, says a teller, and explains that the specific 'magic' that could make this machine fly was only known to Ravana. One story suggests the use of Mercury combined with Ravana's magic to achieve the flying mechanism. This aircraft had the ability to land on a flat ground and Ravana had his own landing locations in Sabaragamuwa. Despite the confidence with which the story tellers locate the air power of Ravana, they themselves seemingly doubt that ability as seen by their deliberate attempts to explain away the flying mechanisms of the Dandu Monaraya. Also, the narrators' efforts to compare this ancient flying machine to a modern air craft with wings and landing sites is motivated by their need to justify the use of magic against rationale science-or even a contest between science and tradition. The flying machine operated by Ravana once again counters the 'demon' narrative-and establishes the king as someone who could imitate modern futuristic science by using 'magic.'

\section{e) Skilled administrator}

Like any emperor, Ravana began his battle for supremacy over a large swathe of land with a smaller confederate in ancient Lanka: he fought a prolonged and a brutal war to expand his territory thereby creating a unified kingdom. In this unified Lanka, King Ravana, as the folktales suggest, was a skilled administrator and a compassionate king who was adored by his subjects. After the unification of Lanka, Ravana conquered the region beyond Lanka (additional details not offered) and went on to 
become a universal monarch with serious concern for environment and the well-being of his subjects. He was famed for meting out severe punishments for those who destroyed forests anywhere in the world. Even the kidnapping of Sita was an event that was initiated only as a response to an injury and insult caused to Ravana's sister by Rama and his friends. Abduction of Sita was an act to motivate Rama to reflect upon and remedy this insult. The Lankan stories go on to suggest that Ravana's demeanour and dignity had a powerful effect on Sita leading to a romantic bond between them during her captivity. The final battle with Rama was an event which Ravana could have won had his own camp did not betray him. Ravana's attachment to Lanka is such that his protective influence exists in the Sabaragamuwa province even after his death.

The king who could wage successful military campaigns to achieve a political objective and then expand his power beyond the Lanka's oceans is far cry from the 'demon' image attributed to him in the Ramayanaya. At the same time, here is a king who could create and execute a fair administrative system with special concern for the natural environment. The creation of Ravana in these narratives is obviously motivated by the creation of Ravana in the Ramayanaya.

These 'folk ideas' embedded in the folktales have offered Ravana a much human and endearing profile, and thus offers him an alternative voice against the classical Indian version of Ramayanaya.

\section{Conclusions/Recommendations}

The Ravana folktales of Sabaragamuwa have offered oral/textual resistance to the original Ramayanaya by subverting the Ravana found therein. They have offered an alternative voice to King Ravana and had neutralized the negative characteristics attributed to him. This act of owning Ravana and offering him redemption through counter narratives is a reflection of how foreign influences are negated by people of a specific region in Sri Lanka. In these narratives the Indian (or foreign) influences in Lanka were a result of the lack of political initiative spearheaded by a strong leader. The moment such a leader arrives, the foreign influences are neutralised as seen from the 'chasing' of Vaishravana from Lanka. Interestingly, the notion of unification of the nation under one powerful ruler is an idea that seems to have occupied the imaginations of the story creators/tellers/hearers of Sabaragamuwa. 
In fact, the Ravana folktales have valorised this idea and have also extended it beyond the shores of the nation into an empire driven by a Lankan personality. Perhaps, in the folkloric imagination of the people of Sabaragamuwa, Ravana is a metaphor for a successful nation which also has the capability to extend its controlling arm to the region. In this metaphoric success, the ruler is compassionate, righteous, intelligent and also a preserver of the environment. This same metaphoric ruler possesses intelligence and is able to manipulate technology to achieve his own ends. One could hardly say that this formula of success of a ruler suggested by the folk narratives exists in the material sphere of the story tellers. Thus, Ravana of Sabaragamuwa is a people's projection of a metaphoric solution to an ailment that is affecting their lives-abuse and corruption of power. And the tales might be a cathartic response to a situation that is too obvious in their social setting. One of the specific instances where this concern is quite obvious is the event of deforestation: Ravana was harsh on those who harmed forests. This could be a narrative solution to the environment damage that is perceived as taking place at an alarming rate in the Sabaragamuwa area owing to gem mining and industrialisation. The storyteller created a narrative to punish such offenders immediately through the intervention of King Ravana-an event that might not be so swift in their material sphere. The Ravana of Sabaragamuwa is thus more than a counter narrative aimed at neutralising foreign influences in Sri Lanka, it is also a narrative that expresses people's wish fulfilment for a leader who could offer meaningful administration for the nation: in the words of a story teller, "a universal king who is admired by all his subjects."

This study is only a preliminary exploration of the Ravana tales, and it has its own short comings specifically in its analysis of the social context of the tales. In the second stage intends to fill those gaps and expand its scope.

\section{References}

Dundes, Alan (1980). Interpreting Folklore. Indiana: Indiana University Press.

Dundes, Alan (Eds.) (1984). Scared Narratives. Readings in the Theory of Myth, University of California Press. 
Gunasoma Gunasekera (2016). Ravana Raju vata gethunu jana katha. Sarasavi.

Kirik, G.S. (1984). On Defining Myths, in Scared Narratives. Readings in the Theory of Myth (Eds, Dundes), University of California Press.

Macherey, Pierre (2016). A Theory of Literary Production. London: Routledge.

Thompson, Stith (1977). The Folktale. London: University of California Press.

Narayan, R.K. (1976). The Ramayana. London: Penguine.

Weerasinghe, Amaradasa (1986). Sinhala Janashruthiya Hederima. Colombo: Sanskruthi. 